\title{
Erratum to: Simultaneous extraction of carotenoids and transfructosylating enzyme from Xanthophyllomyces dendrorhous by a bead beater
}

\author{
Shu-Chih Lee • Tony J. Fang
}

Published online: 10 January 2012

(C) Springer Science+Business Media B.V. 2012

Erratum to: Biotechnol Lett (2011) 33:109-112

DOI 10.1007/s10529-010-0400-z

Unfortunately, author's country name has been published incorrectly in the original publication. The correct affiliation is provided below.

The online version of the original article can be found under doi:10.1007/s10529-010-0400-z.

S.-C. Lee · T. J. Fang $(\bowtie)$

Department of Food Science and Biotechnology, National Chung Hsing University, 250 Kuokuang Road, Taichung City 40227, Taiwan, ROC

e-mail: tjfang@nchu.edu.tw 